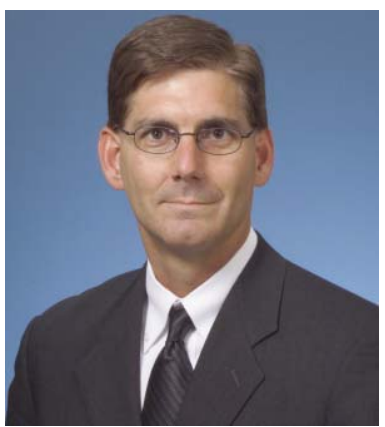

\title{
For Some of Us, Science and Engineering is Hard Work
}

l've always been slower than most optical engineers, and it takes me longer to pick up reading concepts. I usually ask more questions of presenters to understand their concepts from different directions to fully understand them. In graduate school, it always took me much longer to comprehend the material, and I would finally get it after a good bit of hard work. That was the key to my success: hard work. My roommate did not work hard, and he was lazy. But he was also brilliant, and he picked up most concepts with ease. He is still successful today, and he is still brilliant.

As a manager and division superintendent, the first thing I ask about a recommended candidate is whether they are bright and hardworking. In my 15 years of management experience, I can tell you individual success depends on whether someone works hard, or whether they are bright. You can succeed either way, and it is very rare that one person is both brilliant and hardworking. The few that I have met (both hardworking and brilliant) were accompanied by personality flaws to the point that others did not want to work with them. I don't know if this is usually the case since I have only met a few people that fall into this category.

A number of years ago, I hired the son of one of my optical engineers (who has become a good friend over the years). The father was outstanding and well respected. The group to which I assigned the son approached me over a period of months and, finally frustrated, asked me to fire the son. I wanted the opportunity to counsel the son first and I requested that they give me one last shot at talking to him. I bought him lunch at the officer's club (Army base), and we made small talk for awhile. Finally, I told him of my observation that people succeed from either being naturally brilliant or that they get ahead by working hard. I also told him of a second observation, that I did not think he was all that brilliant. Therefore, for him to keep his job, he was going to have to get off his rear end and start working hard. In fact, he needed to do so starting the minute we returned to the lab because his situation was one that had become both urgent and important. I thought the discussion had gone well when I became surprised and he became very embarrassed. A lady who was sitting with a group at a table right next to us got up and wandered over. She had heard the conversation, and she asked me, "would you mind talking to my son?"

I never did talk to her son, and both my friend the optical engineer and his son moved away not too long after this counseling session (it really was not anything I said). I am happy to know that success can come from hard work and that we all do not have to be brilliant. That is, there is hope for all of us if we are willing to invest the time and work at science and engineering.

I dropped my nephew off at the University of Delaware a month ago where he is studying electrical engineering. He reminds me of myself in that he can pick up concepts, but it certainly takes effort. I talked to him a few days ago and I think he has come to realize now that, for him, engineering will take a significant commitment of time and hard work. We all know that there are quite a few distractions at the University, but it is my November wish that my nephew finds that magical balance between homework, studying, and understanding, and still has a great time at school. His new commitment is to work hard during the week and then relax and play during the weekend. He is in my thoughts on most days, and occasionally I will call and give him a "pep" talk to motivate him. My pep talks consist of reminding him to stick to a routine that includes study and homework discipline. I also remind him that at some point, the hard work turns into a fun and rewarding path that includes innovation and creativity. In addition, it doesn't hurt that jobs in science and engineering usually pay well. That is, for those people who are bright and/or hardworking. 